\title{
ENVIRONMENTAL IMPLICATIONS OF AGRICULTURE TRADE IN NEPAL
}

\author{
Krishna P. Pant, Ph. D. ${ }^{4}$
}

\begin{abstract}
International trade of the goods and services has implications to environment via their effects on environment on production and consumption. Agriculture being closely linked with the natural environment the trade of agricultural products and the inputs required for agriculture affects the environment. This paper attempts to identify and analyze trade issues of environmental protection that mainly falls under the purview of Agreement on Technical Barriers to Trade under the World Trade Organization. The analyses will be helpful to identify and understand trade remedy measures that protect environment required for more sustainable agricultural development.
\end{abstract}

\section{Introduction}

Environmental issues entered to Tokyo round of General Agreements on Tariff and Trade (GATT) negotiations (1973 to 1979) with the concerns of some members over the environmental and health effects of the trade liberalization (WTO, 2004). During the Uruguay round negotiations (1986 to 1994) the established the World Trade Organization (WTO) the health concerns and environmental concerns emerged as separate agreements. The health effects are incorporated in Agreement on Application of Sanitary and Phytosanitary (SPS) measures and environmental effects in Technical Barriers to Trade (TBT). Nepal is committed to implement the provisions of SPS and TBT agreements fully.

The WTO adopted a decision on Trade and Environment in 1994 establishing a Committee on Trade and Environment (CTE). It got a broad-based mandate, specifically (a) identifying the relationship between trade measures and environmental measures in order to promote sustainable development, and (b) making appropriate recommendations on whether any modifications of the provisions of the multilateral trading system are required. The aim of the CTE is to make international trade and environmental policies mutually supportive (WTO, 2004). It is believed that trade and environmental policies can complement each other if we plan carefully.

The WTO Members are free to adopt national environmental protection policies provided that they are transparent and do not discriminate between imported and domestically produced like products (national treatment principle), or between like products imported from different trading partners (most-favored-nation clause) having similar environmental implications.

\section{Environment and Agriculture in Nepal}

Nepal's trade policy does not directly mention about the environmental effects of the trade. Neither the environmental policy recognizes the problem of trade on the environment. The Environment Protection Act (1997) does not have any reference to the environmental problems relating to export, import or trade.

\footnotetext{
${ }^{4}$ Senior Agri. Economist, WTO Section, Agribusiness Promotion and Statistics Division, MOAC, Singh

Durbar. Email : kppant@yahoo.com
} 
The trade affects the environment though the path of environmental effects of production and consumption of the traded goods. Some goods are more damaging to the environment than others. If the trades of such environmentally damaging goods are liberalized the environmental problem aggravates. If the production of such goods is environment damaging the exporting country suffers whereas for those products consumption of which damage the environment the consuming country does suffer. In both of the cases, the trade policy of the importing country should be more sensitive to restrict such imports. The agreement on the Technical Barriers to Trade (TBT) gives the legal basis for restricting imports of such environmentally harmful products. The trade policy should have some mechanism to differentiate between environment friendly goods and environmental damaging goods.

There are several recognized environmental effects of trade at local and global levels. The environmental problems may either be resource degradation or pollution.

\section{Resource Degradations}

The major concerns of resource degradations in agriculture sector are the desertification of agricultural land and drying of rivers and wells. Salinization of irrigated terai area is not discussed and the problem is hidden so far. Water table in some parts of terai is going down making more difficult to draw water up. Erratic rainfall like drought or heavy downpour is causing water borne disasters. Deforestation and overgrazing of the pasture land are other problems of resource degradations particularly in hill reason. Though community forestry is found a successful strategy to revive forest and control grazing. Cultivation of steep land in hills with annual crops increases soil erosion. This soil erosion in hills leads to siltation of low lands and river bank cutting due to debris flow. Spread of invasion by alien species like Lantana camera is also creating problem of land management. Irrigation is the largest single use of water. Changing patterns of land use, for example from forest to agriculture, can destroy habitat for plant and animal species. Intensive livestock farming like poultry farms have grown so large that they pose major problems of waste management and disposal, and are sources of air and water pollution. Release of ozone depleting substances like (Chloro fluoro carbon CFC, methyl bromide) is believed to deplete ozone layer. Ultimately, climate change is the problem of global dimension leading to increase in temperature, change in humidity and rainfall, and increase in wind velocity particularly during the dry season.

\section{Pollution}

Environmental pollution can either due to chemicals, radiations or physical matters. Release of pesticides to environment through crop dusting, spraying, baits to pests, fumigation of pest harbors is damaging the natural ecosystem. This results into loss of micro-organisms and pollinators, changes in prey-predator relations, and parasite-host relations. Some part of the chemical fertilizers applied to field crops leach to water bodies both at surface and under the ground leading to water pollution and eutrophication. Agricultural runoff and seepage of fertilizers and pesticides are major sources of groundwater pollution in Terai.

Veterinary drugs and wastes and effluents from veterinary drug and vaccine factories get released to the environment. Similarly, effluent from agriculture processing factories like sugar, breweries, leather, slaughter house and bone release effluent to the environment. If such pollutants are released to the environment untreated lead to sever environmental pollution that may lead to habitat change and cause a loss of biological diversity. Radiations are not commonly used in Nepal, but we have little remedies to control the import of goods that are contaminated with some radiations. 
Physical matters lime particulates and solid waste from perishable agriculture products are other local problems. Transport of bulky agriculture products releases pollutants.

It is vital for countries to internalize the negative environmental externalities that arise in the course of this process. The harm done to the environment must begin to feature as a "cost" in international trade transactions.

\section{Principles of Environmental Protection}

Three fundamental principles of environmental protection are widely respected and these were adopted in the Rio Declaration on Environment and Development (UNCED, 1992).

\section{Principle of Prevention}

Prevention is better than cure. Curing or repairing an environmental damage is generally costly, difficult or sometime impossible. This requires action before the problem occurs. Environmental impact assessment (EIA) and initial environmental examinations (IEE) are the measures followed to this end.

\section{Shared and differential responsibilities}

Some environmental problems are local, some are trans boundary and some others are global in nature (Table 1). All the countries in the world have shared responsibilities of protecting the environment. But different countries have different level of responsibilities. Under the Kyoto Protocol, only developed countries which have signed have targets for greenhouse gas emission reductions.

Table1. Local, Regional and Global Effects of environmental problem (Pollution)

\begin{tabular}{|c|c|}
\hline Local effects & Global effects \\
\hline$>$ Heavy metals in air, soil and plants & Changes of the climate due to \\
ozone depletion and the \\
greenhouse effect.
\end{tabular}

Polluter-pays principle

The polluters should have to bear the full cost of pollution. It is based on rational of cost internalization. In reality the prices of the many goods do not reflect the full cost of environmental damage. This is the reason why the environment is deteriorating.

The polluters should pay the full cost of the environmental damage that their activities produce. This increases the costs of production and hence shifts the supply curve back (Figure 1). The producers attempt to pass the costs to consumers along the price of the goods involved. This leads to an increase in the price of the goods. This then discourages consumption of more pollution-intensive goods. This market mechanism protects the environment. 
Figure 1. Polluters pay principle decrease production and increase price.

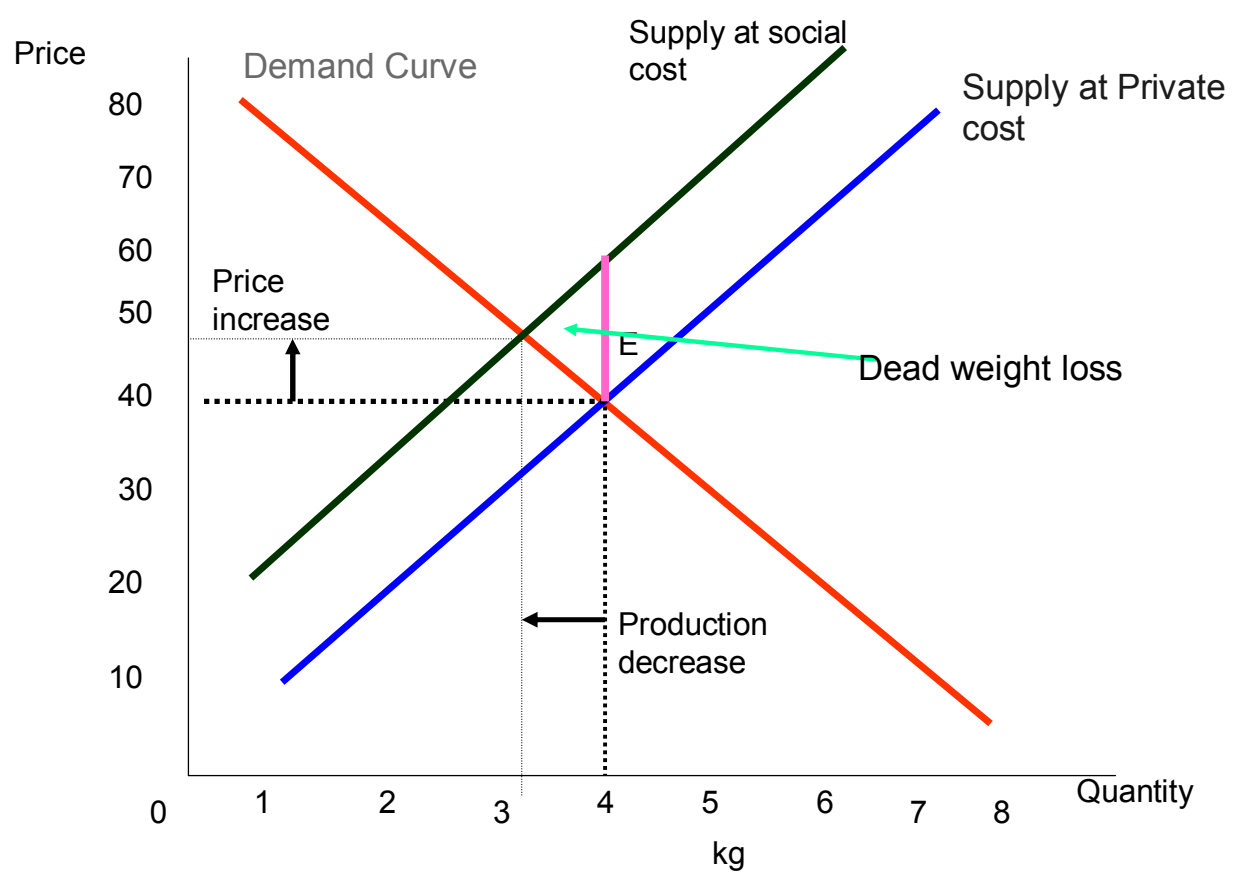

The environmental costs born by the society is paid by the producers under this principle. Some part of this cost is paid by the consumers through increased price. It means, the social welfare (the surpluses of the producers and consumers) de decreases. But this decrease is less than what actually we save from the protection of the environment. The net saving to the society is the avoidance of the dead weight loss.

\section{Precautionary principle}

The Rio declaration includes the precautionary principle that the lack of conclusive scientific evidence does not justify inaction, particularly when the consequences of inaction may be devastating or when the costs of action are negligible. Risk analysis is a difficult task, because our knowledge of environmental processes and ecosystem intricacy is never perfect. The understanding is based on an evolving foundation of scientific research.

\section{World Trade Organization and the Environment}

International trade rules under WTO in the area of agriculture have complex implications for sustainable development. Trade concerns have dominated the debate on domestic agricultural policy. Liberalized market for agricultural products has a number of complex environment and development impacts. For instance, access to world markets can provide access to food when local harvests fail. Imported food can also provide a more sustainable alternative to farming marginal land, allowing better management of natural resources. As a member of the WTO, Nepal has liberalized trade and importing many of the agricultural products. But by importing the agriculture products that we can produce we are effectively importing unemployment. 
The WTO has several pieces of legal texts scattered over different agreements relevant to the environment. Some provisions of the GATT (1994) are directly relevant to trade-related environmental issues. These include the non-discrimination principles of most-favourednation and national treatment, and the general exceptions to GATT rules. Non-discrimination is the main principle on which the rules of WTO hinge. It ensures that national environmental protection policies cannot arbitrarily discriminate between foreign and domestically made products, or between products imported from different trading partners (GATT, 1994 Arts I and III). Another principle of tariff only regime of the GATT (1994) is violated in the context of a number of environmental disputes in which countries have imposed bans on the importation of certain products (GATT, 1994 Article XI).

The General Agreement on Trade in Services (GATS) allows to address environmental concerns by allowing WTO members to adopt policy measures that would normally be inconsistent with GATS if this is necessary to protect human, animal or plant life or health (identical to GATT Article XXb). The Agreement on Technical Barriers to Trade (TBT) seeks to ensure that product specifications, also known as technical regulations and standards, and conformity assessment procedures, do not create unnecessary obstacles to trade. But the preamble of TBT recognizes the rights of the members to adopt such measures to the extent they consider appropriate level of protection (ALP) to protect legitimate interest that include human, animal or plant life or health, or the environment.

Similarly, Agreement on Sanitary and Phytosanitary Measures (SPS) deals with food safety, and human, animal and plant health and safety regulations. The SPS agreement recognizes members' rights to adopt measures but stipulates that they must be based on a risk assessment, should be applied only to the extent necessary to protect human, animal or plant life or health, and should not arbitrarily or unjustifiably discriminate between members where similar conditions prevail. The SPS Agreement complements the TBT Agreement to meet the legitimate interests. It allows members to adopt SPS measures for environmental purposes, but subject to such requirements as risk assessment, non-discrimination and transparency.

The Agreement on Trade-Related Aspects of Intellectual property (TRIPS) refers explicitly to the environment in Section 5, which deals with patents. It says (in paragraphs 2 and 3 of Article 27 - Arts 27.2 and 27.3) that members can make certain inventions ineligible for patenting to protect human, animal or plant life or health, to avoid serious harm to the environment. A member can exclude an invention from patentability if it believes the invention has to be prevented (within its territory) for these and certain other objectives. Plants and animals (other than microbes) do not have to be eligible for patenting. These provisions are designed to address the environmental concerns related to intellectual property protection. The TRIPS Agreement allows members to refuse to patent inventions that may endanger the environment.

In the preamble, the Agreement on Agriculture (AoA) reiterates members' commitment to reform agriculture in a manner that protects the environment. Among the green box measures that are permitted expenditures under environmental programs are included with some conditions. Such exemption enables the members to capture positive environmental externalities.

The 2001 Doha Declaration has a section dealing with the Committee on Trade and Environment (CTE). The focus is on effects of environmental measures on market access, the relevant provisions of the intellectual property agreement, labeling requirements for 
environmental purposes, technical assistance, sharing expertise for national environmental reviews and environmental aspects of the Doha negotiations (Source: www.wto.org).

It is feared that the environmental requirements can impede trade and even be used as an excuse for protectionism. The answer is not to weaken environmental standards, but to set appropriate standards and enable exporters to meet them. The CTE gives particular attention to this subject and its effects on developing countries. The effect of environmental measures on market access, especially for developing countries and in particular to the least developed among them, is one of the items on the committee's work program. The committee should consider that the WTO members consider that the protection of the environment and health are legitimate policy objectives.

Other related issue is the environmental labeling. Environmental labeling schemes are becoming more complex, causing concerns about developing countries' and small businesses' ability to export. The question is how does the manufacturer use labeling to inform consumers about environmental protection without jeopardizing these weaker players. Labeling is one of the subjects assigned to the CTE. In addition to labeling, this includes standards and technical regulations, and packaging, and recycling requirements. The use of eco-labels 5 by governments, industry and non-governmental organizations (NGOs) is increasing.

\section{Agriculture Trade and Environment}

Agricultural trade is the most contentious subject of negotiation under Doha agenda. The negotiations for caps and reductions on the use of agricultural export subsidies, domestic support programs and tariffs are under way. Agriculture is a central element of the Doha negotiations, and continues to be a contentious topic. Some countries primarily the USA and Argentina are producing genetically modified organisms (GMOs) for major crops like cotton, soybeans, canola, maize and rice. The modern breeders have rational that if property used, GMO can reduce the use of harmful pesticides and also increase production. Environmental concerns over the use of GMOs include the possibility that the insect resistant traits of GMOs will generate other more dangerous pests and parasites. They also include the risk of crossbreeding with traditional relatives, raising the risk of reducing genetic variation, one major component of biodiversity. Human health effect of GMO is not disproved. Under the precautionary principle, one can restrict the import of GMO.

Many terrestrial and aquatic plant and animal species that are either cultivated and domesticated or left in the wild remain under exploited in terms of their potentials to provide food, fibre, energy, wood, medicines, and other products useful to man constitute the agrobiodiversity. Many of them are being harvested beyond their natural regenerative capacity. Several indigenous species of crops, animals, birds, and fishes play significant roles on the traditional food systems in different physiographic regions. Nepal has a wide variety of domesticated plants and animals, including over 400 species of agro-horticultural crops and about 200 species of vegetables (Jha et al. 1996).

WTO is not an environmental protection agency and its competency is limited to trade, and to those aspects of environmental policies that are trade related and may have significant scope for countries to pursue non discriminatory national environmental policies.

With a view to enhancing the mutual supportiveness of trade and environment, members of WTO agreed the relationship between existing WTO rules and specific trade obligations set

\footnotetext{
${ }^{5}$ Eco-labels are labeling products according to environmental criteria.
} 
out in multilateral environmental agreements. There is agreement for the reduction or, as appropriate, elimination of tariff and non-tariff barriers to environmental goods and services.

\section{Conclusions}

Environmental standards of production are emerging as a major issue in international trade. SPS and TBT are more or less concerned with environments. Nepal needs to review and revise existing legislations and enact new legislations in line with SPS/TBT requirements and to meet legitimate objectives of protecting health and environment. The government should give priority to strengthen existing capacity of production units to minimize the environmental effects of the production units.

Nepal being one of the least developed country (LDC) members of WTO, its immediate policy focus is on poverty reduction. More focused studies are required to redefine the environmental policies to juxtapose with the trade policies and poverty reduction.

Nepal need to reduce tariff for environment protection equipments and other goods and increase for those having higher risk to the environment. As Nepal's Himalayan environment is fragile, we can restrict or even put a ban on environmentally hazardous products

\section{REFERENCES}

1. Adhikari, R., 2004: TRIPS Agreement: Implications for biodiversity and poverty in Nepal. SWATEE http://www.swatee.org.np

2. Ahmed, S., Sattar, Z. 2004: "Impact of Trade Liberalization Looking at the Evidence" in Economic and Political Weekly, Vol., XXXIX No., 36, September 4, 2004, pp40594067

3. Andrew, D., Dahou, K. and Steenblik, R., 2004: Addressing Market Access Concerns of Developing Countries Arising From Environmental and Health Requirement : Lessons From National Experiences. OECD Trade Policy Working Paper. No 5. 24 Sept., 2004. http://www.oecd.org/trade

4. Busse, M., 2004: Trade Environment Regulation and the World Trade Organization. World Bank Policy Research Working Paper 3361. Washington D.C., : World bank

5. Charnovitz, S., 2002: "The Law of Environmental "PPMs" in the WTO: Debunking the Myth of Illegality." Yale Journal of International Law, Vol. 27 (1): 59-110.

6. Chaturvedi , S., Nagpal, G., 2003: “WTO and Product - Related Environmental Standards Emerging Issues and Policy Options " in Economic and Political Weekly, Vol., XXXVIII No., 1, Jan., 4, 2003 pp66 - 74

7. Nordstrom, H. and Scott V., 1999: "Trade and Environment," (special studies \#4). Geneva: WTO. <http://www.wto.org/english/res_e/booksp_e/special_study_4_e.pdf

8. Shrestha, P. M., 2004: “ Process of Nepal's Accession to the WTO and its implication for Nepal " in Action Aid Nepal , Law Associates Nepal , A Discussion Programmes on Legal Regime on Nepal's Ratification to the WTO. Kathmandu pp 5 - 8.

9. Shrestha, P. R., Shakya, B.M., 2002: Status of Standardization and Conformity Assessment in Nepal. Country Paper ( Nepal ). World Tr@de Net Tropical Agreement, Manila, the Philippines, 3 - 5 December, 2002.

http://www.intracen.org/worldtradenet/docs/whatsnew/tbe_philippines_dec2003/c ountrypaper_nepal.pdf 
10. Stevens, C., 1993: Harmonisation, Trade and the Environment. International Environmental Affairs 5 ( 1) : 42 - 49 http://ciesin.columbia.edu/docs/008-062/008$062 \mathrm{html}$

11. UNCDF, 1992: Earth Summit, Rio Declarationon Environment and Development, United Nations Conference on Environment And Development, Rio

12. UNEP , 1999 : Trade Liberalisation and The Environment. Lessons learned from Bangladesh, Chile, India, Philippines, Romania and Uganda : A Synthesis Report. Nairobi : UNEP http://www.unep.org

13. Vitalis, Vangelis, 2004: "Trade, Agriculture, The Environment And Development: Reaping The Benefits Of Win-Win-Win?" IIED/ICTSD. <http://www.ictsd.org/dlogue/2004-07-14/Vangelis.pdf>.

14. WTO, 1999: The Legal Texts: The Results of the Uruguay Round of Multilateral Trade Negotiations, Cambridge University Press, UK.

15. WTO, 2003: Understanding the WTO (second edition)

16. WTO, 2004: Trade and Environment background, the WTO Secretariat, www.wto.org

17. WTO, 2005: Trade And Environment During GATT, http://www.wto.org 